\title{
Struktur Tata Kelola Global Value Chains Produk Kopi dalam Perdagangan Kopi Global : Studi Komparatif Kopi Indonesia dan Kopi Vietnam
}

\author{
Primadiana Yunita \\ Universitas Brawijaya \\ Email: primadiana@ub.ac.id
}

\begin{tabular}{l}
$\frac{1}{1}$ Artikel info \\
\hline Artikel history: \\
Diterima 30 April 2021 \\
Diterima dalam bentuk \\
revisi 10 Mei 2021 \\
Diterima dalam bentuk \\
revisi 18 Mei 2021
\end{tabular}

Keywords: governance; GVCs; coffee; global trade.

Kata Kunci:

tata kelola; GVCs; kopi; perdagangan global.

\begin{abstract}
Coffee is one of the most traded commodities in the world. Indonesia and Vietnam are two countries in Southeast Asia which are the leading exporters in the global market. However, the interesting thing from the last few years is that Vietnam can compete with Indonesia to become the second position of global coffee exporters, while Indonesia has dropped to the fourth position. This phenomenon is inseparable from the many problems in the management of the coffee product value chain in Indonesia. In looking at the competitiveness of Indonesian coffee products and Vietnamese coffee in global competition, it is important to look at the production chain, to company competition and the governance of the two countries' governments in the coffee sector. This research is a qualitative descriptive study. In addition, this study also uses a comparative study method by collecting data through observation and documentation. The result of this study is that there are differences in the governance structure of the global value chains of Indonesian and Vietnamese coffee products. The difference is in the input and output structure, which includes a decrease in the productivity of Indonesian coffee compared to Vietnamese coffee. The next difference is the geographical considerations related to coffee production in Vietnam and Indonesia. Furthermore, in carrying out product governance, both Vietnam and Indonesia also have different ways. both in institutional control related to global value chains and cooperation mechanisms.
\end{abstract}

\begin{abstract}
Abstrak: Kopi adalah salah satu komoditas paling potensial untuk diperdagangkan di dunia. Indonesia dan Vietnam adalah dua negara di Asia Tenggara yang menjadi eksportir terkemuka di pasar global. Namun hal yang menarik dari beberapa tahun belakangan ini adalah Vietnam dapat menyaingi Indonesia menjadi posisi kedua eksportir kopi global sedangkan Indonesia turun di peringkat keempat. Fenomena ini sangat tidak terlepas dari banyaknya permasalahan dalam tata kelola nilai rantai produk kopi di Indonesia. Dalam melihat daya saing produk kopi Indonesia dan kopi Vietnam di persaingan global, maka penting untuk melihat rantai produksi, hingga persaingan perusahaan dan tata kelola pemerintah kedua negara dalam sektor kopi. Penelitian ini adalah penelitian deskriptif kualitatif. Selain itu dalam penelitian ini juga menggunakan metode studi komparatif dengan mengumpulkan data melalui observasi dan dokumentasi. Hasil dari penelitian ini adalah terdapat perbedaan dalam struktur tata kelola global value chains produk kopi Indonesia dan Vietnam. Adapun perbedaan tersebut yakni pada struktur input dan output yang mencakup menurunnya produktivitas kopi Indonesia dibandingkan kopi Vietnam. Perbedaan selanjutnya adalah pada pertimbangan geografis yang berhubungan pada produksi kopi di Vietnam dan Indonesia. Lebih lanjut dalam melakukan tata kelola produk baik Vietnam dan Indonesia juga mempunyai cara berbeda. baik pada kontrol lembaga yang berkaitan dengan global value chains dan mekanisme kerja sama.
\end{abstract}




\section{Pendahuluan}

Negara-negara di dunia menjadikan komoditas perkebunan sebagai sumber devisa kedua setelah minyak bumi dalam perdagangan global. Salah satu komoditas perkebunan yang berperan penting adalah kopi. Hal ini karena kopi telah memberikan sumbangan yang cukup besar bagi devisa negara produsen, dengan menjadi salah satu sumber ekspor non migas. Selain itu, komoditas ini dapat menjadi penyedia lapangan kerja dan sumber pendapatan bagi petani pekebun kopi maupun bagi pelaku ekonomi lainnya yang terlibat dalam budidaya, pengolahan, serta dalam mata rantai pemasaran kopi di dunia (United States Department of Agriculture, 2014). Industri kopi secara global mempekerjakan lebih kurang 25 juta pekerja dari seluruh dunia (World coffee trade, 2020).

Pentingnya kopi dalam ekonomi global saat ini dapat tergambar dalam beberapa fenomena, antara lain: (a) lebih dari 90 persen produksi kopi berasal dari negara berkembang, sementara konsumsi justru berada terutama di negara-negara industri; (b) dalam periode pasca Perang Dunia II, kopi telah menjadi komoditas kedua paling berharga yang diperdagangkan setelah minyak; (c) upaya untuk mengontrol perdagangan kopi internasional telah ada sejak awal abad ke-20, yang membuat kopi menjadi salah satu komoditas pertama yang diregulasi secara internasional; (d) sejumlah negara berkembang, bahkan mereka dengan pangsa pasar ekspor global yang rendah, mengandalkan kopi untuk pendapatan ekspor mereka, sehingga kopi merupakan sumber pendapatan bagi jutaan petani kecil dan buruh tani di seluruh dunia; dan (e) pemerintah negara produsen kopi secara historis memperlakukan kopi sebagai komoditas strategis (Ponte, 2002).

Sebanyak 60 negara yang terdaftar di Persatuan Bangsa-Bangsa (PBB) merupakan produsen kopi. Data tahun 2013 dari lembaga perdagangan kopi dunia menyebutkan bahwa Brazil adalah negara produsen kopi terbesar di dunia, disusul oleh Vietnam di posisi kedua dan Indonesia di posisi ketiga (World coffee trade, 2020).

Hal berbeda dengan tahun 2013, ditunjukkan pada data tahun 2019 yang menyebutkan bahwa saat ini Indonesia menempati peringkat keempat dunia sebagai negara pengekspor kopi dengan volume ekspor sebesar 666.000 Ton. Nilai ekspor Indonesia saat ini kalah jauh jika dibandingkan dengan Vietnam, yang mencapai 1.367.000 Ton. Hal ini sangat memprihatinkan mengingat bahwa pada tahun 1986, kopi Vietnam belum cukup diperhitungkan. Produktivitas Vietnam saat itu hanya menempati urutan 10 ke bawah. Tidak hanya itu, hal ini juga menimbulkan pertanyaan mengenai hal-hal apa sajakah yang membuat ekspor kopi Indonesia semakin melemah besarannya dalam kurun waktu 6 tahun ke belakang.

Indonesia adalah negara dengan keunggulan geografis terutama untuk produk kopi. Perkebunan kopi yang tersebar di penjuru Indonesia membuat hampir setiap daerah di Indonesia mampu menghasilkan jenis varietas kopi unggulan (baik Robusta maupun Arabica) dan juga memiliki ciri khas rasa serta aroma yang berbeda, sebut saja Kopi Aceh 
Gayo, Kopi Toraja, Kopi Bali Kintamani.

Penurunan yang cukup signifikan pada produk kopi Indonesia berbanding terbalik dengan pertumbuhan yang cukup meningkat tajam dalam industri kopi Vietnam pada beberapa tahun ini membawanya sebagai negara produsen kopi terbesar kedua setelah Brazil. Sekitar 6 persen dari total produksi Vietnam saat ini dikonsumsi secara domestik.

Untuk melihat bagaimana perkembangan Vietnam serta sekaligus melihat penurunan produk kopi Indonesia dalam perdagangan kopi global salah satu analisa yang dapat digunakan adalah Global Value Chains (GVCs). GVCs merupakan konsep yang dapat digunakan dalam menganalisis permasalahan dari perspektif ekonomi dan politik. Dalam konsep ini dijelaskan mengenai jaringan aktifitas yang dilakukan oleh perusahaan-perusahaan secara menyeluruh. Tujuannya adalah untuk menjelaskan ruang organisasi dari produksi, perdagangan dan konsumsi ekonomi global (Ponte, 2002).

Global Value Chain (GVCs) menjadi instrumen penting dalam menganalisis perdagangan global. Para ahli ekonomi menyatakan bahwa peran global value chains mampu meningkatkan nilai tambah pada sektor industri barang dan jasa. Keterbukaan pasar yang telah mempermudah lalu lintas produk dari satu negara ke negara lainnya tentunya akan berimplikasi positif jika negara mampu meningkatkan daya saing dan nilai tambah produknya. Hal ini dikarenakan GVCs memiliki 4 dimensi yang melibatkan struktur output input,pertimbangan geografis, struktur pemerintah serta kelembagaan yang ada. Selain itu, dalam GVCs juga dapat dilihat mengenai pertumbuhan sektor kopi Indonesia dan kopi Vietnam serta dinamikanya. Hal inilah yang kemudian melatarbelakangi penelitian ini. Berdasarkan latar belakang di atas, maka penelitian ini berusaha untuk menjelaskan bagaimana struktur tata kelola (Global Value Chains) produk kopi Indonesia dan kopi Vietnam dalam perdagangan kopi global.

\section{Global Value Chains}

Global Value Chains (GVCs) merupakan semua aktivitas yang mencakup suatu perusahaan, di dalam atau di luar negeri, untuk membawa sebuah produk kepasaran, dari mulai berupa konsepsi sampai penggunaan akhir (Sturgeon, 2013).

Menurut seorang ahli yakni (Gereffi \& Fernandez-Stark, 2011) global value chain adalah:

"A commodity chain encompasses the whole range of activities involved in the desain, production, and marketing of product. The value chain also called the commodity chain and production consumption chain is described as a comprehensive set of activities that are required to bring a product from a concept stage to marketing and consumption of and product".

Konsep ini menyatakan bahwa rantai nilai komoditas meliputi semua kegiatan yang tekait dari hulu hingga hilir penjualan suatu produk. Rantai nilai juga disebut dengan rantai komoditi, kemudian rantai produksi sampai konsumsi. Perdagangan dunia, investasi dan produksi semakin terorganisir di sekitar rantai nilai global ini. Kegiatan-kegiatan dalam rantai nilai global berkisar dari desain, produksi, pemasaran, logistik dan distribusi untuk mendukung ke kostumer akhir. Hal ini mungkin dilakukan oleh perusahaan yang sama atau dibagi antara beberapa perusahaan. Ketika mereka telah menyebar, rantai nilaipun menjadi semakin global. 
Tentu saja ekonomi yang sesungguhnya tidak begitu sederhana, linear ataupun searah. Rantai nilai yang mendalam dibentuk oleh lembaga dan rezim di mana mereka berada. Dalam tingkat yang paling sederhana, rantai nilai dapat dikatakan terdiri dari empat langkah, 1) penelitian, desain, dan pengembangan produk; 2) input; 3) produksi; dan 4) pemasaran, penjualan, distribusi, dan layanan purna jual.

Terdapat 4 dimensi dasar dalam metodologi GVCs untuk melihat perubahan rantai produksi satu ke rantai lainnya antara lain.

1. Struktur input dan output, menjelaskan proses perubahan dari bahan mentah menjadi produk jadi.

2. Pertimbangan geografis, dimana bahan tersebut diperoleh serta siapa yang membelinya.

3. Struktur tata kelola, sejauh mana pemerintah mengendalikan rantai nilai ini.

4. Serta lembaga-lembaga mana saja yang terkait dalam konteks GVCs.

Struktur input-output dan cakupan geografis dalam GVCs digunakan untuk mendeskripsikan garis konfigurasi dari rantai tertentu. Struktur pemerintahan memisahkan antara kategori producer-driven dan buyer-driven. Rantai producer-driven biasanya ditemukan pada sektor dengan syarat teknologi dan kapital yang tinggi dengan produk yang dihasilkan seperti pesawat terbang, komputer. Sedangkan buyer-driven lebih ditemukan pada sektor intensif tenaga kerja dengan produk seperti garmen, alas kaki, dan lainnya. GVCs cenderung memiliki beberapa karakteristik dasar dari ekonomi global saat ini, antara lain: (Gereffi \& Fernandez-Stark, 2011).

a. Keterkaitan pertumbuhan ekonomi. Dalam GVCs kegiatan ekonomi terfragmentasi dan tersebar di seluruh negara. Saat ini, lebih dari setengah impor manufaktur dunia adalah barang setengah jadi (barang primer, bagian dan komponen, dan produk setengah jadi), dan lebih dari 70 persen impor dunia adalah layanan menengah, seperti layanan bisnis. Ekspor termasuk nilai tambah yang diimpor dari luar negeri.

b. Spesialisasi perusahaan dan negara-negara dalam tugas-tugas dan fungsi bisnis. Saat ini, sebagian besar barang dan bagian pertumbuhan jasa yang ada di dunia, berbeda denggan perusahaan dan negara-negara yang mengkhususkan diri dalam fungsi dan tugas-tugas tertentu yang secara kolektif merupakan GVCs. Namun, banyak kebijakan yang masih didasarkan pada asumsi bahwa barang dan jasayang diproduksi hanya dalam satu negara.

c. Jaringan pembeli dan pemasok global. Dalam GVCs peran sentral dimainkan oleh kontrol perusahaan dan koordinasi kegiatan dalam jaringan pembeli dan pemasok, dan perusahaan multinasional (MNCs). Kebijakan mempengaruhi bagaimana jaringan ini terbentuk dan di mana kegiatan mereka berada.

d. Driver kinerja ekonomi baru. Dalam GVCs, perdagangan dan pertumbuhan bergantung pada sumber efisien input luar negeri, serta akses terhadap produsen dan konsumen akhir di luar negeri. Fragmentasi produksi di GVCs merupakan sarana meningkatkan produktivitas dan daya saing. GVCs juga mempengaruhi tenaga kerja pasar, terutama dengan mempengaruhi permintaan kelompok keahlian yang berbeda.

Analisis GVCs merupakan alat analisis yang digunakan untuk memahami secara lebih baik terhadap keunggulan kompetitif, untuk mengidentifikasi dimana nilai pelanggan dapat ditingkatkan atau penurunan biaya, dan untuk memahami secara lebih baik hubungan perusahaan dengan pemasok/supplier, pelanggan, dan perusahaan lain dalam industry (Gereffi \& Fernandez-Stark, 2011). GVCs mengidentifikasikan dan menghubungkan berbagai 
aktivitas stratejik di perusahaan dengan sifat GVCs tergantung pada sifat industri dan berbeda-beda untuk perusahaan manufaktur, perusahaan jasa dan organisasi yang tidak berorientasi pada laba (Widarsono, 2009).

Fragmentasi produksi di negara-negara bukanlah suatu fenomena baru. Yang baru adalah skala dan ruang lingkup yang semakin meningkat. Perusahaan saat ini dapat menurunkankan produksi di seluruh dunia karena biaya perdagangan telah menurun secara signifikan karena kemajuan teknologi telekomunikasi, perangkat lunak manajemen informasi serta biaya komputer pribadi yang lebih murah, dapat diandalkan sehingga telah menurunkan biaya kegiatan koordinasi yang kompleks di antara perusahaan yang memiliki jarak yang jauh. Kemajuan pesat dalam teknologi informasi dan komunikasi semakin meningkatkan daya jual berbagai barang dan jasa. Selain itu, pengiriman kemas, standardisasi, otomatisasi dan intermodalitas lebih besar dari barang telah memfasilitasi pergerakan barang di GVCs, meskipun jarak masih penting.

Analisis GVCs melihat upgrade dimulai dengan proccess upgrade (misalnya produser mengadopsi teknologi yang lebih baik untuk meningkatkan efisiensi), kemudian lanjut ke product upgrade di mana kualitas atau fungsi dari produk diupayakan dengan menggunakan bahan berkualitas tinggi atau sistem manajemen mutu yang lebih baik, dan kemudian ke functional upgrade di mana perusahaan mulai merancang produk sendiri dan mengembangkan kemampuan pemasaran dan branding serta mulai memasok untuk pasar akhir atau ke konsumen secara langsung. Selanjutnya, proses upgrade mungkin juga mencakup upgrade antar sektoral atau yang dikenal sebagai sectoral upgrade.

Dalam makalahnya tahun 1994, Gereffi mengidentifikasi dua jenis driven ekonomi diihat dari pilihan kebijakan ekonomi yang diambil. Pertama adalah rantai buyer-driven, di mana perusahaan-perusahaan utama adalah pembeli akhir seperti rantai ritel dan produsen produk bermerek seperti produk konsumen akhir non-tahan lama (misalnya, pakaian, alas kaki dan makanan). Tipe pemerintahan yang kedua diidentifikasi oleh Gereffi adalah rantai produser-driven. Di sini kompetensi teknologi dari perusahaan utama mendefinisikan daya saing rantai. Dalam sebuah makalah mengenai pertimbangan-pertimbangan inisiatif GVCs, diidentifikasi beberapa pola pemerintahan GVCs:

i. Rantai hirarkis merupakan operasi yang sepenuhnya diinternalisasi oleh perusahaan, umumnya pola ini terintegrasi secara vertikal;

ii. Kuasi-hirarkis (atau penangkaran rantai) yang melibatkan pemasok atau pelanggan kelas menengah dengan rendahnya tingkat kemampuan yang membutuhkan dukungan tingkat tinggi dan merupakan subyek dari manajemen rantai pasokan yang dikembangkan dari perusahaan;

iii. Rantai hubungan relasional dan modular antara perusahaan dan pemasok utama dengan para pelanggan dalam rantai, dengan rendahnya tingkat rantai dalam pemerintahan yang sering terjadi karena pemasok utama dalam rantai memiliki kompetensi mereka sendiri yang tergolong unik dan dapat beroperasi secara independen dari perusahaan utama; dan

iv. Rantai pasar klasik yang mewakili hubungan jangka panjang seperti yang ditemukan di banyak pasar komoditas.

Untuk negara-negara berkembang dan perusahaannya, peluang potensial untuk bergabung GVCs cenderung substansial. Integrasi ke GVCs telah menjadi salah satu pilar penting dari kebijakan negara berkembang untuk pembangunan ekspor (Nicita et al., 2013). 
GVCs memungkinkan produsen dalam rantai global untuk mendapatkan pengetahuan manajemen modern dan informasi langsung mengenai standar kualitas dan teknologi, agar menjadi lebih kompetitif. Produsen juga cepat belajar tentang pola permintaan pasar yang tinggi dan preferensi konsumen di pasar tersebut. Partisipasi dalam GVCs juga bisa membuat eksternalitas ekonomi yang luas untuk negara-negara berkembang, seperti peningkatan lowongan pekerjaan, peningkatan teknologi dan keterampilan, peningkatan kapasitas produktif dan diversifikasi ekspor dengan nilai tambah. Eksternalitas ini kemudian akan meningkatkan daya tarik mereka untuk investasi asing langsung (FDI).

\section{Metode Penelitian}

Penelitian secara kualitatif memungkinkan peneliti untuk menjawab pertanyaan penelitian dengan menganalisis tingkah laku, tindakan, struktur sosial dan memunculkan fakta-fakta yang tidak dapat dikuantifikasikan atau diukur secara pasti. Berdasarkan cakupan tersebut, maka metode kualitatif akan lebih akurat menjawab rumusan masalah dalam penelitian ini.

Penelitian ini dilakukan dengan menggunakan tipe penelitian literature review atau kajian literatur. Literature review merupakan penelitian yang berisi uraian tentang teori, temuan dan bahan penelitian lain, (Zainal, 2007) dengan berfokus pada studi komparatif antara kopi Indonesia dan kopi Vietnam. Data yang dipakai dalam analisis penelitian ini adalah data sekunder. Data sekunder dalam penelitian ini berasal dari buku, jurnal, artikel website, dan penelitian yang sudah dilakukan sebelumnya.

Selain itu, dalam penelitian ini juga menggunakan. Menurut (Anggito \& Setiawan, 2018) penelitian komparatif adalah sejenis penelitian deskriptif yang ingin mencari jawaban secara mendasar tentang sebab-akibat, dengan menganalisis faktor-faktor penyebab terjadinya ataupun munculnya suatu fenomena tertentu.

\section{Hasil dan Pembahasan}

Dalam studi komparasi antara produk kopi Indonesia dan produk kopi Vietnam terdapat 4 dimensi dasar dalam Global Value Chains yang digunakan untuk melihat rantai produksi kopi pada masing-masing negara, yaitu :

\section{Struktur Input dan Output Produk Kopi Indonesia dan Vietnam}

Struktur input-output dan cakupan geografis dalam GVCs digunakan masing masing negara dalam produk kopi ini dapat dikategorisasikan sebagai buyer driven daripada producer driven. Hal ini dikarenakan pengelolaan kopi baik di Vietnam maupun Indonesia sampai dengan saat ini belum merambah ke penggunaan teknologi apabila ditelusuri dari hulu ke hilir. Hal ini dibuktikan dengan data bahwa sekitar 95 persen dari luas lahan yang ditanami kopi yang menurut pemerintah mencapai sekitar 1,2 juta hektar pada tahun 2011 dikelola oleh petani kecil, dan sekitar 90 persennya berada di pulau-pulau diluar Jawa (Kementerian Pertanian, 2013). Para petani umumnya mengelola perkebunan kopi campur yang berukuran rata-rata satu hektar.

Tidak seperti di beberapa negara produsen lain, seperti India, Brasil dan Kolombia, hampir tidak ada penanam kopi mandiri yang berukuran menengah di Indonesia. Perkebunan besar relatif tidak banyak, dan semuanya terdiri dari pelaku korporasi atau badan usaha milik negara (PTPN). Produksi Indonesia didominasi oleh kopi jenis Robusta (kira-kira 85\% dari 
total produksi). Indonesia pada umumnya memproduksi kopi Robusta berkualitas lebih rendah yang: i) diekspor dalam bentuk biji kopi hijau; ii) diolah untuk konsumsi di pasar domestik yang terus meningkat; maupun iii) diolah untuk dijual ke pasar ekspor.

Hasil kopi per hektar jauh lebih rendah di Indonesia daripada di Vietnam, yang menjadi pesaing langsung Indonesia di pasar-pasar yang bervolume tinggi/berbiaya rendah untuk kopi Robusta (Tabel 1). Meskipun biaya produksi lebih tinggi, yang sebagian disebabkan oleh investasi di tingkat usaha tani, di Vietnam, Tabel 1 memperlihatkan bahwa tingkat keuntungan hasil panen kopi untuk setiap hektarnya jauh lebih tinggi. Berdasarkan perhitungan lain, petani di Indonesia hanya memproduksi rata-rata sekitar $600 \mathrm{Kg} / \mathrm{ha}$ dibandingkan dengan petani di Vietnam yang mencapai $3.000 \mathrm{~kg} / \mathrm{ha}$, dimana pengelolaannya dilakukan secara intensif. Hasil kopi yang rendah di Indonesia disebabkan oleh tidak terpeliharanya perkebunan rakyat selama puluhan tahun. Selain itu, biaya tenaga kerja, energi dan logistik lebih murah di Vietnam dibandingkan di Indonesia. Meskipun ada kekhawatiran yang besar terhadap kesinambungan hasil kopi dalam jangka panjang di Vietnam lihat, misalnya, (D’haeze, D., Deckers, J., Raes, D., Phong, T. A., \& Loi, 2005), jelas produsen kopi Indonesia saat ini masih kalah bersaing, bahkan dalam kategori di tingkat produsen ini.

Tabel 1

Perbandingan produktivitas kopi di Vietnam dan Indonesia (Robusta)

\begin{tabular}{lll}
\hline & Indonesia & Vietnam \\
\hline Biaya Produksi (USD/ton) & 574 & 1087 \\
\hline Hasil rata-rata (Kg biji hijau/ha) & 800 & 2400 \\
\hline Net margin (USD/ha) & 873 & 1447 \\
\hline
\end{tabular}

Bagi Indonesia, Vietnam adalah pesaing serius untuk kopi robusta. Karena kuantitas produksi kopi Vietnam jauh lebih besar daripada kuantitas produksi kopi Indonesia yang berarti ekspor kopi Vietnam jauh lebih besar daripada ekspor kopi Indonesia. Vietnam mengalahkan Indonesia dalam dominasi pasar robusta dunia. Ada hal lain yang menarik berkaitan dengan produk biji kopi.

Menurut pendapat di website https://espressocoffeeguide.com/best-coffeebeans/ maupun https://www.homegrounds.co/best-coffee-beans-bucket-list/ dari pengujian sepuluh biji kopi berkarakter terbaik di dunia, tiga kopi Indonesia masuk ke dalam sepuluh biji kopi unggulan yaitu kopi Mandailing, kapi Toraja, dan kopi Jawa. Hal ini berbeda dengan Vietnam di mana biji kopi Vietnam tidak masuk ke dalam sepuluh produk kopi unggulan dunia. Lalu, bagaimana dengan selera peminum kopi terhadap kopi Indonesia dan Vietnam?, Studi dari (Atmadji et al., 2018) tentang permintaan kopi Malaysia terhadap kopi Indonesia dan Vietnam menunjukkan bahwa peminum kopi Malaysia lebih menyukai kopi Indonesia dibanding kopi Vietnam. Kopi Vietnam bagi peminum kopi Malaysia hanya merupakan minuman kopi selingan dan tetap memilih kopi Indonesia sebagai minuman kopi utamanya.

Dari studi tersebut menunjukkan bahwa kopi Indonesia adalah kopi yang berkarakter kuat dibanding kopi Vietnam. Artinya permintaan kopi Indonesia lebih inelastik dibanding permintaan kopi Vietnam di Malaysia. Kuantitas produksi kopi Vietnam yang tiga kali lipat 
lebih banyak daripada kopi Indonesia berakibat pada besarnya suplai kopi Vietnam pada pasar kopi dunia. Namun karena kopi Vietnam bukanlah produk premium maka diduga Vietnam menggunakan strategi harga yang lebih murah daripada harga yang ditawarkan pesaingnya. Sebagai pesaing yang terdekat dari ekspor kopi Vietnam, eksportir kopi Indonesia belum dapat membuat harga kopi Indonesia menjadi lebih murah dan mengandalkan kualitas dan keragaman kopi robusta sebagai faktor unggulan dalam bersaing ketat dengan Vietnam.

II. Pertimbangan Geografis dalam Produksi Kopi Vietnam dan Indonesia

Keadaan geografis Indonesia adalah salah satu faktor yang membuat produk kopi Indonesia menjadi khas baik citarasa maupun jenisnya. Dengan keadaan geografis tersebut mempunyai berbagai implikasi terhadap pembangunan sektor dari segi logistik, pengembangan organisasi industri, dan pembinaan reputasi atau brand nasional. Biaya angkutan kopi di Indonesia sangat tinggi, seringkali merugikan produsen yang letaknya jauh dari pusat-pusat kegiatan ekspor utama (export hubs). Daerah-daerah penghasil kopi di Indonesia cukup beragam dari segi sistem produksi, kualitas kopi, pengolahan pasca panen, struktur rantai nilai, struktur dukungan kelembagaan, peranan sektor swasta dan kondisi lingkungan.

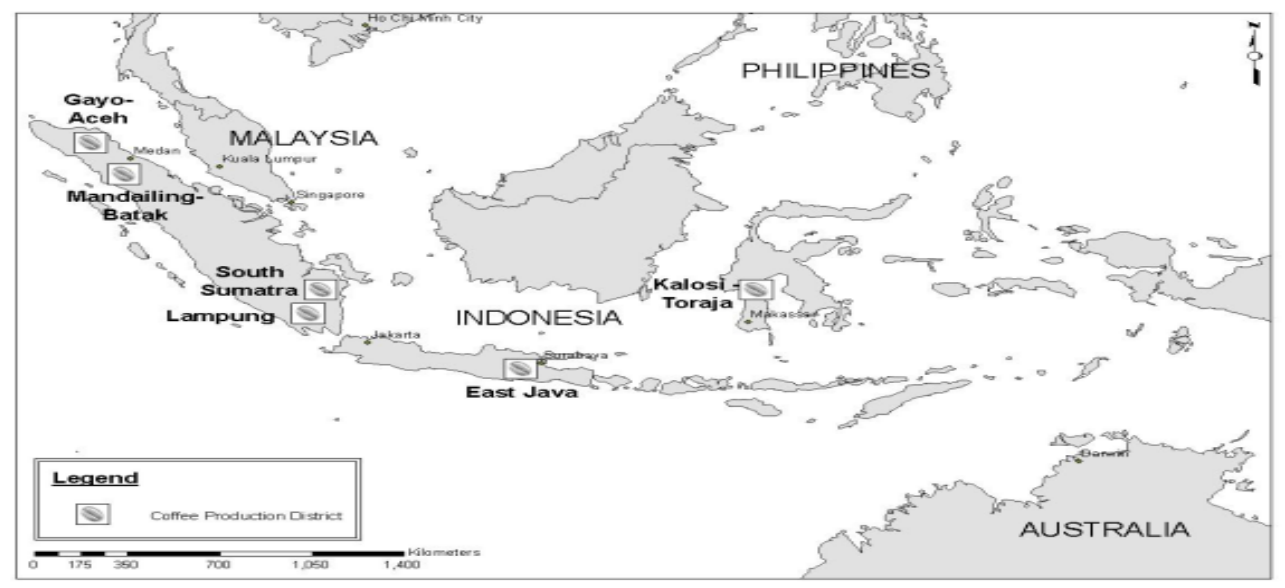

Gambar 1

\section{Daerah-daerah tanaman kopi utama di Indonesia}

Lebih lanjut, keberagaman sistem produksi kopi di daerah menunjukkan bahwa tantangan penerapan teknologi budidaya kopi juga beragam, dan secara umum membutuhkan intervensi yang sesuai dengan kebutuhan daerah. Pertukaran informasi atau berbagi pengetahuan antar daerah relatif sedikit, sehingga menghambat strategi pembangunan yang dikoordinasikan secara nasional, dan memperlihatkan perlunya beberapa program intervensi yang berorientasi pada daerah. Oleh karena itu, kualitas kopi yang cukup beragam di berbagai daerah tersebut menunjukkan tantangan-tantangan spesifik bagi inisiatif pemasaran di tingkat nasional. Sehingga, tidak mudah untuk berbicara mengenai rantai perdagangan industri kopi Indonesia secara keseluruhan.

Berbeda dengan Vietnam, daya saing ekspor Vietnam yang selalu meningkat di pasar kopi dunia diduga terkait dengan faktor kekhususan aset (asset specificity). Vietnam berada di daerah sub tropis yang memiliki perbedaan iklim yang tegas, enam bulan hujan 
dan enam bulan berikutnya kemarau. Iklim demikian sangat cocok untuk budidaya kopi karena pada waktu proses berbunga, tanaman kopi membutuhkan cuaca kering. Jika hujan maka bunganya akan rontok sehingga tidak menjadi putik. Selain itu, tanah di Vietnam lebih subur, disertai pula etos kerja petaninya yang berdisiplin tinggi dan progresif. Produktivitas kopi yang tinggi di Vietnam dan Brasilia masing-masing sekitar 2 ton dan 3 ton per ha, dimungkinkan karena sistem pengelolaan pertaniannya sangat intensif dan pemupukan dilakukan dengan tepat sesuai dengan dosis yang dianjurkan agar memperoleh hasil yang maksimal. 


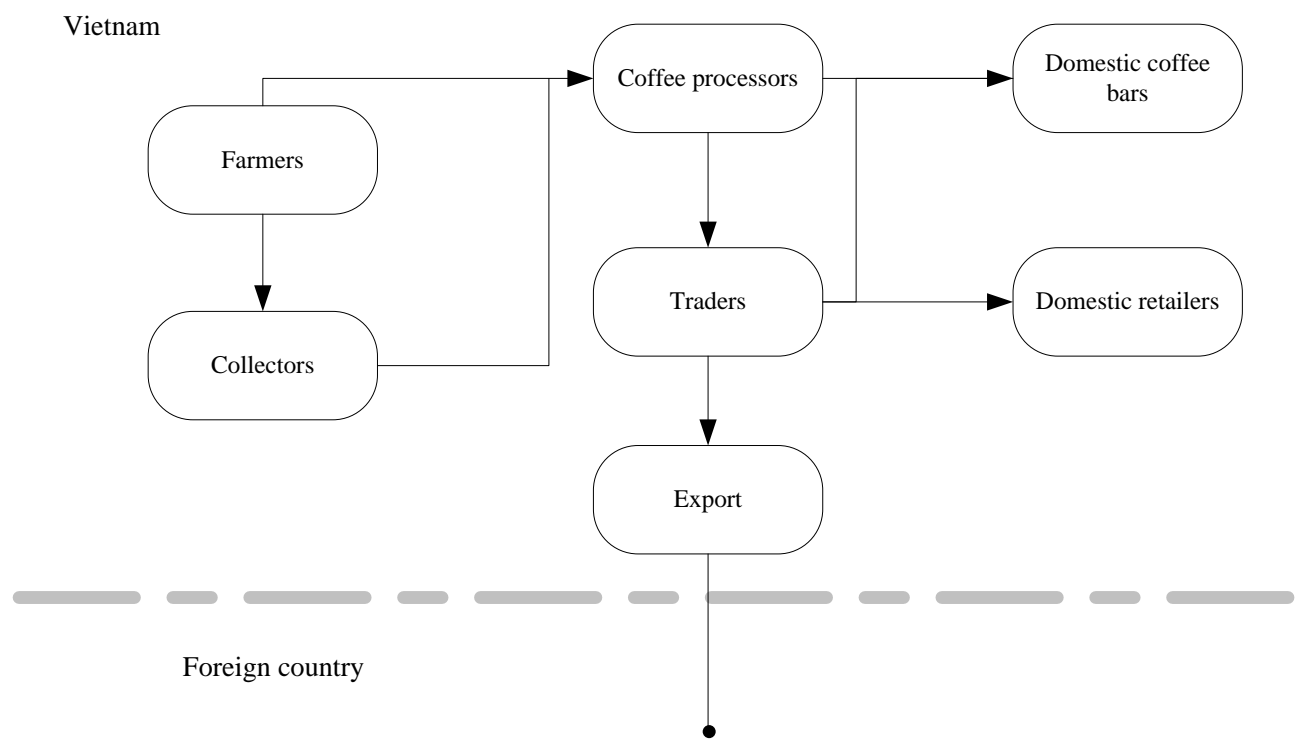

III. Struktur Tata Kelola Produk Kopi Vietnam dan Produk Kopi Indonesia

Dalam struktur tata kelola produk kopi perbedaan mendasar antara Indonesia dengan Vietnam adalah peranan pemerintah/negara dalam mengendalikan rantai perdagangan kopi. Di Vietnam ada organisasi/entitas utama yang berfokus mengurusi masalah kopi yakni Asosiasi Kopi \& Kakao Vietnam (VICOFA). VICOFA sudah ada mulai tahun 1990, adapun aktivitas utama VICOFA adalah menjadi jembatan antara pemerintah dan bisnis. VICOFA juga memberikan informasi mengenai harga dan volume ekspor, dalam mengelola dan mengendalikan rantai produksi hingga perdagangan kopi Vietnam menerapkan pengelolaan campuran antara pemerintah dengan pihak swasta, akan tetapi lebih banyak memberikan porsi kepada swasta. Secara sederhana berikut adalah bagan yang menggambarkan bagaimana tata kelola domestic Vietnama pada produk kopi :

Pemain utama dalam rantai nilai kopi Vietnam dijelaskan di bawah ini :

1. Petani

Petani memainkan peran terpenting dalam rantai nilai karena mereka mengambil bagian dalam fase produksi, fase pertama dalam rantai tersebut. Ada tiga jenis perkebunan kopi: perkebunan yang diberi hak milik atas tanah oleh negara, perkebunan yang telah menerima kontrak dari pertanian yang dikelola negara, dan petani yang mengolah tanah dan lahan hutan mereka sendiri, tanpa hak milik.

Kopi yang dipanen diproses dengan tiga cara. Yang pertama adalah kopi hijau: buah kopi yang dipanen dari semak-semak. Kedua, kopi kering: kopi yang dipanen dikeringkan dengan metode sederhana. Dan metode terakhir adalah kopi rush: kopi diproses secara kasar dengan metode pengolahan kering. Cara pengolahan kering berarti mengeringkan buah kopi dengan sinar matahari atau dengan mesin (beberapa rumah tangga membeli mesin 
pengering), kemudian menggosoknya, membuang kulitnya dan hanya menyimpan bijinya (penggilingan). Sebagian besar rumah tangga melakukan semua tahapan sendiri. Hanya sedikit rumah tangga yang mampu membeli mesin untuk pemrosesan pasca panen. Hampir semua rumah tangga mengeringkan kopi di bawah sinar matahari dan kemudian menyewa mesin untuk memproses kopi 'rush', daripada menyimpannya sebagai kopi hijau. Cara ini murah dan mudah. Sekitar 4,5 ton biji kopi diproses menjadi 1 ton kopi bubuk.

\section{Perantara}

Peran perantara dan agen adalah mengangkut kopi dari petani ke perusahaan pengolah atau pengekspor. Agen dan perantara membeli sekitar 90 persen dari hasil kopi. Ada banyak agen dan tengkulak, sehingga harga tidak terlalu fluktuatif untuk tiap grade kopi. Namun, harga untuk kelas yang berbeda bervariasi, dari VND 50 hingga VND 100 per kg. Agen dan tengkulak memiliki dua cara untuk membeli kopi, baik dengan mengumpulkan biji kopi di tempat sendiri atau dengan menggunakan alat transportasi sendiri seperti truk, membeli kopi di rumah petani dan diangkut langsung ke pabrik pengolahan kopi. Agen ini dapat berupa perusahaan swasta atau anak perusahaan (di tingkat provinsi, komune atau desa) produsen pengolahan atau pengekspor. Staf dari agen-agen ini digaji oleh pabrik.

Perantara/agen pengumpul kopi seringkali tidak memiliki kegiatan lain, selain hanya mengangkut kopi dari petani, tetapi pengumpul kopi/ agen kopi di Vietnam berbeda. Setelah membeli kopi, agen sering melakukan aktivitas pemrosesan kasar untuk menghilangkan kotoran (dalam kasus kopi rush yang sudah diproses oleh rumah tangga) atau menggiling dan memoles kering (kopi kering) untuk membuat kopi bubuk, yang dijual ke perusahaan pengolah atau pengekspor. Keuntungan utama mereka berasal dari kegiatan pengolahan dan pengumpulan kasar.

3. Industri pengolahan/ Pengekspor

Perusahaan pengolahan atau pengekspor sering membeli kopi melalui agen mereka sendiri atau menandatangani kontrak dengan agen pengumpul swasta dan seringkali membeli kopi rush. Hanya perusahaan yang memiliki jalur pengolahan basah yang membeli kopi hijau dari rumah pertanian. Setelah membeli bahan masukan, perusahaan mengolah kopi.

Untuk menyiapkan biji kopi untuk ekspor, perusahaan memprosesnya kembali untuk memenuhi standar ekspor dan mengklasifikasikan kopi ke dalam berbagai tingkat kualitas. Namun, setelah diolah kembali, kopi tersebut masih memiliki banyak kekurangan, karena teknologi yang tidak memadai. Kopi ekspor sering dipengaruhi oleh tiga masalah: kelembaban, biji hitam dan pecah, dan kotoran. Banyak pelanggan yang mengkhawatirkan keamanan kopi Vietnam karena rawan terinfeksi Ochratoxin A. Perusahaan pengolahan kopi melakukan pemanggangan dan penggilingan pada sebagian kecil kopi rush (3-6 persen), dan menjual produk jadinya di dalam negeri. pasar. Namun, hanya Perusahaan Trung Nguyen yang memiliki jaringan distribusi nasional, dengan 400 agen resmi.

4. Pasar kopi instan Vietnam

Baru-baru ini, untuk memonopoli pasar, perusahaan terkemuka kopi Vietnam, Vinacafé, telah memperkenalkan produk baru, kopi instan 4-in-1 campuran atau kopi ginseng (dengan tambahan gula, susu bubuk dan ginseng). Hal tersebut menandakan bahwa pasar domestic Vietnam hampir mencapai titik jenuh. Nescafé juga meluncurkan campuran kopi instan 3-in-1 di bawah tiga merek secara bersamaan, masing-masing memiliki paket dan 
slogan yang sangat berbeda. Dari sini dapat disimpulkan bahwa pangsa pasar mereka sekarang terancam oleh perusahaan yang memperkenalkan "campuran kopi" di pasar. Banyak perusahaan kecil dalam negeri yang terburu-buru berinvestasi di bidang ini. Ada banyak alasan untuk fenomena ini. Pertama, perkembangan kuat Vinacafé Bien Hoa, organisasi terkemuka dengan pangsa pasar 50,4 persen pasar kopi instan Vietnam, kini mengarahkan banyak investor baru untuk memproses kopi jenis ini. Kedua, perusahaan kecil mungkin kekurangan informasi prospek pasar yang akurat. Menurut penelitian Taylor Nelson Sofrees (TNS), Vietnam secara umum menunjukkan tren penurunan konsumsi kopi dibandingkan dengan jenis minuman lain (Pham et al., 2020).

Berbeda dengan Vietnam, dalam rantai produksi kopi ini peranan negara sangat minim di sektor kopi di Indonesia. Tidak ada badan yang secara khusus dibentuk di bawah Kementerian Pertanian berkaitan dengan tata kelola kopi. Adpaun kemudian organisasi yang paling lama dibentuk di Indonesia dan berkaitan dengan kopi adalah AEKI (Asosiasi Eksportir Kopi Indonesia). AEKI didirikan sebagai rasa kebersamaan dalma menyatukan langkah para pelaku ekspor kopi dalam menjawab permasalahan pemerintah untukmengambil bagian dalam tata niagakopi yang mana sejak tahun 1969 Organisasi Kopi Dunia (ICO) menerapkan kuota bagi para anggotanya. AEKI sendiri resmi terbentuk pada tahun 1979.

Belajar dari Vietnam, maka Indonesia perlu melibatkan sektor swasta melalui kemitraan pemerintah-swasta dimulai pada hulu, soal teknik-teknik pertanian yang lebih baik dapat diperkenalkan kepada petani kopi Indonesia. PISAgro Partnership for Sustainable Agriculture, bersama dengan Sustainable Coffee Partnership (SCOPI), menawarkan model potensial untuk kerjasama dan kemitraan pemerintah-swasta dalam pemberian penyuluhan. Yang juga sama pentingnya adalah mengakui bahwa perbaikan produktivitas hendaknya dinilai secara lebih luas daripada sekedar jumlah kilogram per hektar. Sebaliknya, produktivitas perlu dipertimbangkan dalam kaitannya dengan strategi mata pencaharian yang lebih luas dan peranan yang dimainkan sektor kopi dalam strategi itu, dengan demikian juga dipertimbangkan aspek kebutuhan dan ketersediaan tenaga kerja serta pentingnya bentuk lain dari penghasilan pertanian dan di luar pertanian. Demikian pula, produktivitas sistem pertanian kopi hendaknya diukur dari segi total kebutuhan sumber daya dan kemungkinan degradasi lingkungan yang ditimbulkan oleh proses produksi, yang bisa menjadi salah satu perbedaan dari produksi Vietnam dan akhirnya lebih berkelanjutan dalam jangka panjang.

Dalam mendukung tata kelola rantai perdagangan kopi Indonesia, perlu juga adanya intervensi untuk mendukung organisasi produsen yang masih belum maju di sektor kopi Indonesia. (Wulandari, 2019) enyatakan bahwa untuk memperbaiki akses pasar dan diferensiasi produk dapat dilakukan melalui sertifikasi keberlanjutan, "salah satu prasyarat adalah menjadikan organisasi petani sebagai organisasi produsen." Pendapat serupa dinyatakan oleh banyak pihak dan, dengan demikian, patut dipertimbangkan. Namun, pada dasarnya ada tiga bentuk organisasi yang relatif berbeda berbicara soal produk kopi di Indonesia dan dapat dimobilisasi: (i) koperasi; (ii) kelompok tani; dan (iii) organisasi petani. Koperasi meliputi pembentukan badan hukum yang kemudian dapat melakukan kegiatankegiatan bisnis dan harus memenuhi protokol organisasi formal (rapat berkala, peranan pimpinan, pembukuan, iuran anggota, dan sebagainya). Tidak adanya asosiasi petani kopi yang aktif di Indonesia dan kurangnya perwakilan yang sah dalam pembahasan kebijakan dan pertanggungjawaban program semakin menghambat pengembangan industri kopi. 
Pemerintah Indonesia, mungkin melalui Kementerian Perdagangan, dapat mendukung asosiasi petani kopi (seperti APKI) dan membangun dana untuk peningkatan kapasitas berbasis hasil, serta melaksanakan program-program pelatihan dan pembinaan yang diperlukan.

Lebih lanjut, jika berbicara mengenai potensi pertumbuhan yang besar terjadi di pengolahan hilir kopi Robusta menjadi kopi instan, kopi 3-in-1, dan produk-produk siap minum untuk pasar domestik maupun internasional. Pemerintah Indonesia perlu memastikan kerangka kebijakan yang mendukung industrialisasi hilir. Pertumbuhan tersebut terjadi karena adanya investasi yang relatif besar untuk memenuhi kebutuhan teknologi di subsektor pengolahan ini. Sebaliknya, penyangraian (roasting) kopi Arabika Indonesia kemungkinan besar dilakukan oleh UKM, dan kemungkinan akan tetap difokuskan pada pasar kopi khusus domestik yang terus berkembang dalam waktu dekat ini, dibandingkan pasar ekspor. Dalam kedua kasus tersebut, sistem perdagangan terbuka diperlukan untuk memastikan agar pabrik pengolah mempunyai akses ke berbagai kopi internasional yang diperlukan untuk pencampuran kopi, meskipun total volume impor biji kopi hijau diperkirakan masih rendah. Demikian pula, investasi asing untuk pengolahan hilir diperkirakan akan tetap memainkan peranan penting dalam mendorong inovasi dan daya saing di sektor kopi.

Hal lain dalam struktur tata kelola produk kopi keberhasilan Vietnam ini tidak terlepas dari keterlibatan pemerintah yang relatif besar dalam mengembangkan kopi. Pemerintah Vietnam membangun irigasi, jalan-jalan di sentra-sentra produksi kopi, melakukan penelitian, memberikan penyuluhan dan mengucurkan kredit serta memberikan hak pengolahan dengan luas areal tidak terbatas hingga 50 tahun. Produktivitas kopi di Vietnam lebih tinggi dibandingkan dengan di negara-negara produsen kopi lainnya karena kopi banyak diusahakan oleh perusahaan negara (Kustiari, 2016). Sementara di Indonesia, sebagian besar diusahakan oleh petani yang memiliki keterbatasan modal dan sumber daya manusia, sehingga kopi yang diproduksi oleh petani mutunya kebanyakan masih asalan.

\section{Lembaga-Lembaga yang terkait dalam GVCs Kopi Vietnam dan Indonesia}

Selain aktor-aktor yang telah disebutkan sebelumnya pada struktur tata kelola di Vietnam. Vietnam juga mempunyai lembaga lain yang terkait dalam konteks Global Value Chains, yaitu Pusat Pertukaran Kopi Buon Ma Thuot (Buon Ma Thuot Coffee Exchange Centre). Pusat Pertukaran Kopi Buon Ma Thuot (BCEC) didirikan untuk melayani kepentingan produsen dan pedagang kopi. Anggotanya melakukan transaksi dengan mengajukan penawaran atau meminta pesanan kopi standar. Syarat untuk permintaan penawaran harus memiliki deposit yang cukup. Permintaan pesanan harus untuk jumlah kopi minimum, yang diatur oleh peraturan BCEC. Pembeli mentransfer uang ke rekeningnya di bank kliring sesuai dengan nilai kontrak. Penjual kopi disimpan di gudang, dengan resi gudang diterbitkan dan disimpan di BCEC. BCEC bekerja dengan 3 organisasi:

- Bank kliring: Bank untuk Teknologi dan Perdagangan Vietnam (Techcombank) menyediakan semua layanan keuangan dan perbankan kepada BCEC;

- Pemeriksaan kualitas: Pengawas dan perusahaan inspeksi Vietnam untuk kopi dan produk pertanian untuk impor dan ekspor (CafeControl) mengawasi kualitas dan kuantitas kopi; 
- Manajemen gudang: JSC Kopi Giang bertanggung jawab atas manajemen gudang, pemrosesan dan pengiriman produk.

Dengan demikian, aktivitas BCEC serupa dengan aktivitas bursa. Saat ini terdapat sekitar 20 perusahaan kopi Vietnam yang terdaftar sebagai anggota BCEC.

Melihat keberhasilan Vietnam dalam tata kelola rantai produk kopi maka hal yang paling penting memang adalah membangun lembaga-lembaga untuk menangani produk kopi yang lebih kuat dengan keterlibatan yang kuat dari para pemangku kepentingan. Adapun lembaga yang kemudian juga berkaitan dengan Global Value Chains kopi Indonesia adalah :

1. Dekopi atau Dewan Kopi.

Dekopi dibentuk dan dikukuhkan tahun 2018. Dekopi diharapkan akan menjadi partner yang baik bagi pemerintah dan swasta. Bagi pemerintah Dekopi akan mengidentifikasi persoalan kopi, regulasi, standar, dan program sehingga pemerintah mendapat masukan yang baik untuk perbaikan sistem perkopian Indonesia. Dekopi juga mempunyai tujuan untuk mensejahterakan pelaku usaha kopi Indonesai dari hulu sampai ke hilir khususnya petani. Dewan Kopi dapat menjadi penghubung dan mendukung pengorganisasian Kemitraan Pemerintah-Swasta yang bertanggung jawab untuk melaksanakan kegiatan-kegiatan pembangunan di daerah-daerah produsen kopi.

2. Asosiasi Kopi Spesial Indonesia (AKSI)

AKSI dibentuk pada tahun 2007 oleh beberapa kelompok petani kopi Indonesia, eksportir, roaster dan pengecer untuk meningkatkan kualitas mutu serta kuantitas perkopian di Indonesia. AKSI didirikan pada tahun 2008 dan keanggotaannya terbuka bagi individu, lembaga dan komunitas kopi yang berhubungan dengan kopi spesial (Sebelumnya hanya Arabika tetapi kemudian Robusta terbaik juga tersedia) dari Indonesia. Semua yang termasuk petani Individu, kelompok tani, pembeli, roaster, eksportir, pengecer dan individu / orang yang memiliki misi yang sama.

Semboyan dari Asosiasi adalah "Istimewa dalam keanekaragaman" yang merupakan cerminan dari keragaman rasa kopi Indonesia, berbagai kalangan petani yang menanamnya dan lingkungan di mana yang ditanam menyebar dari Barat ke Timur dari Kepulauan Indonesia. Setiap ekosistem dan tanah Indonesia telah diciptakan untuk kopi dengan profil cupping unik sesuai dengan tempat tumbuhnya kopi. Misi dari AKSI diantaranya adalah meningkatkan mutu (Quality), Jumlah (Quantity) dan Harga Pasar (Market Price) kopi spesialti Indonesia. Merupakan forum yang efektif sebagai mediator dan fasilitator bagi semua anggota yang terlibat untuk menghasilkan pendapatan dan kehidupan yang lebih baik. Membantu pembelajaran/edukasi di tingkat budidaya, proses, Sertifikasi Uji Citarasa (Q dan R Grader), sertifikasi biji kopi (Q Coffee License) serta pemasaran kopi spesialti Indonesia di pasar lokal dan Internasional.

Koordinasi industri di tingkat nasional yang lebih baik akan membantu mengendalikan kepentingan dan keterlibatan sektor swasta yang tinggi dalam kegiatan-kegiatan di seluruh rantai nilai. Akan tetapi pendirian lembaga-lembaga yang berkaitan dengan kopi di Indonesia memang masih tergolong baru. Sehingga belum mampu secara efektif mendongkrak rantai pertambahan nilai pada produk kopi terutama di bagian hilir. Sampai saat ini dalam pemasaran dan branding kopi Indonesia lebih dikenal dengan brand kopi yang sifatnya lebih menonjolkan memiliki sifat/karakteristik kualitas yang muncul dari kondisi geografis lokal seperti Mandheling, Gayo, Toraja. 
Selanjutnya, diperlukan juga promosi model-model kemitraan dengan sektor swasta yang melibatkan petani, pedagang dan pabrik penyangrai/pengolah (roasters/processors) yang mendorong alih pengetahuan mengenai persyaratan kualitas, pengelolaan lingkungan dan peningkatan produktivitas. Model-model inovatif Kemitraan Pemerintah-Swasta memungkinkan pemerintah memanfaatkan secara efektif dinamika sektor swasta untuk memberikan pelayanan teknis dan yang lebih baik kepada petani kopi Indonesia, termasuk yang berkaitan dengan proses di hulu seperti nutrisi tanah, peremajaan tanaman dan penanggulangan hama. Tidak berhenti sampai disitu, proses pertambahan nilai memang diperlukan tindakan yang menyeluruh dari hulu sampai hilir, sehingga mendukung industrialisasi hilir (penyangraian/roasting) adalah bentuk peningkatan nilai tambah secara fungsional dalam rantai nilai, dan dianggap sebagai salah satu tujuan ekonomi yang sangat strategis bagi Pemerintah Indonesia. Peningkatan nilai tambah hilir dari sumber daya alam menjadi tema kunci dalam Master Plan Percepatan dan Perluasan Pembangunan Ekonomi Indonesia (MP3EI) 2011, yang telah disetujui oleh Presiden Joko Widodo.

\section{Kesimpulan}

Struktur tata kelola global value chains pada produk kopi Indonesia dan Vietnam dapat dilihat dari 4 hal, Pertama, dari struktur input dan output, produktivitas kopi Indonesia sangat jauh tertinggal apabila dibandingkan dengan produksi kopi Vietnam. Akan tetapi baik Indonesia maupun Vietnam sama-sama mendasarkan produk kopi sebagai produk buyerdriven, karena pengelolaannya masih menitikberatkan pada padatnya tenaga kerja bukan pada penggunaan teknologi.

Kedua, pertimbangan geografis yang berhubungan pada produksi kopi di Vietnam dan Indonesia. Masing-masing negara sebenarnya mempunyai keunggulan geografis yang mendukung dalam proses memproduksi kopi. Akan tetapi, sektor kopi Indonesia cukup besar, beragam secara internal dan tersebar lebih luas di beberapa wilayah di Indonesia.

Ketiga, struktur tata kelola produk kopi Vietnam dan Indonesia. Dalam tata kelola produk kopi Vietnam mempunyai struktur yang lebih jelas dan rantai koordinasi yang lebih baik dari hulu hingga hilir bila dibandingkan Indonesia. Di Indonesia struktur dukungan formal dari negara dapat dikatakan sangat minim.

Keempat, lembaga-lembaga yang berkaitan dengan konteks GVCs produk kopi Vietnam dan Indonesia. Perbedaan adalah pada kontrol dan mekanisme kerja sama. Vietnam lebih banyak mengedepankan adanya kerja sama dan koordinasi antara pemerintah dan swasta, akan tetapi lebih banyak memberikan porsi pada swasta. Sedangkan Indonesia lembagalembaga yang dapat mendukung proses pertambahan nilai produk kopi diinisiasi oleh petani dan pelaku usaha kopi sendiri, dan kebanyakan lembaga yang dibentuk masih baru. Sehingga belum bisa dilihat kinerjanya secara efektif. 


\section{Bibliografi}

Anggito, A., \& Setiawan, J. (2018). Metodologi penelitian kualitatif. CV Jejak (Jejak Publisher).

Atmadji, E., SA, E. S. A., \& Suhardiman, Y. H. (2018). Comparison analysis of imported coffee of Malaysia from Indonesia and Vietnam. Economic Journal of Emerging Markets, 10(1), 93-98.

D'haeze, D., Deckers, J., Raes, D., Phong, T. A., \& Loi, H. V. (2005). Dampak lingkungan dan sosial ekonomi dari reformasi kelembagaan terhadap sektor pertanian Vietnam: Penilaian kelayakan lahan untuk kopi Robusta di daerah Dak Gan. Pertanian, Ekosistem \& Lingkungan, 105((1)), 59-76.

Gereffi, G., \& Fernandez-Stark, K. (2011). Global value chain analysis: a primer. Center on Globalization, Governance \& Competitiveness (CGGC), Duke University, North Carolina, USA.

Kementerian Pertanian. (2013). Outlook Komodoti Kopi 2013, Pusat Data dan Sistem Informasi Pertanian, Kementerian,.

Kustiari, R. (2016). Perkembangan pasar kopi dunia dan implikasinya bagi Indonesia.

Nicita, A., Ognivtsev, V., \& Shirotori, M. (2013). Global supply chains: Trade and economic policies for developing countries. Citeseer.

Pham, T. T., Nguyen, D. T., Đào Thi, L. C., \& Hoàng, T. L. (2020). Preparing Vietnam for new rules on international market: Preparing Vietnam for new rules on international market (Vol. 257). CIFOR.

Ponte, S. (2002). Thelatte revolution'? Regulation, markets and consumption in the global coffee chain. World Development, 30(7), 1099-1122.

Sturgeon, T. J. (2013). Global value chains and economic globalization. Massachusetts Institute of Technology.

United States Department of Agriculture. (2014). Coffee: World Market and Trade.

Widarsono, A. (2009). Strategic Value Chain Analysis: Suatu Pendekatan Manajemen Biaya.

World coffee trade. (2020). No Title. http://www.thecoffeeguide.org/coffee-guide/worldcoffee-trade/, diakses pada 18 Maret 2020

Wulandari, E. L. A. (2019). Analisis Strategi Diferensiasi Terhadap Keunggulan Bersaing Untuk Meningkatkan Kinerja Pemasaran Ikm Kopi Di Kabupaten Temanggung. UNNES.

Zainal, A. (2007). Metodologi Penelitian pada Bidang Ilmu Komputer dan Teknologi Informasi; Konsep, Teknik, dan Aplikasi. Fakultas Ilmu Komputer Universitas Indonesia. 